\title{
RELEVANSI HUKUM DAN HAK ASASI MANUSIA DENGAN AGENDA REFORMASI: DIMENSI NASIONAL DAN INTERNASIONAL*
}

\author{
${ }^{*}$ Ismail Marzuki ${ }^{1}$, Faridy ${ }^{2}$ \\ Universitas Nurul Jadid, Paiton Probolinggo \\ ${ }^{1}$ e-mail: ismail.2805@ gmail.com* \\ ${ }^{2}$ e-mail: faridy.hukum@gmail.com
}

\begin{abstract}
In life, humans certainly cannot be separated from their social interactions with others. Friction between individuals or between nations is something that is inevitable. That is because the understanding of the legal system and culture of a different society. The difference in opinion certainly needs to be harmonized by not locking up the meeting room of everyone's expression. From here, the existence of legal rules/norms on the one hand becomes important in people's lives. On the other hand, the recognition, respect and protection of human rights are also important to be accommodated. Therefore, this article examines the law as a means of maintaining social order, and human rights as a set of rights that describe the existence of human freedom in expressing their actions, and how relevant they are to the reform agenda, namely enforcing the law against violators of human rights seriously, both in national and international.
\end{abstract}

Keywords: Relevant; Law; Human Rights.

\begin{abstract}
Abstrak
Kehidupan manusia tentu tidak lepas dari interaksi sosialnya dengan manusia yang lain. Gesekan antar individu dengan individu yang lain atau antar bangsa dengan bangsa yang lain merupakan sesuatu yang niscaya. Hal itu disebabkan pemahaman terhadap tata hukum dan budaya dari suatu masyarakat berbeda satu sama lain. Perbedaan pandangan tersebut tentu perlu diharmonisasikan, tentu dengan tidak mengunci rapat ruang berekspresi setiap orang. Dari sinilah keberadaan aturan/norma hukum di satu sisi menjadi penting dalam kehidupan masyarakat, di sisi lain adanya pengakuan, penghormatan, dan perlindungan terhadap hak asasi manusia juga penting untuk diakomodir. Oleh karena itu, artikel ini mengkaji tentang hukum sebagai salah satu sarana untuk mempertahankan ketertiban sosial, dan hak asasi manusia sebagai serangkaian hak yang mendeskripsikan eksistensi kebebasan manusia dalam mengekspresikan tindakannya, serta bagaimana relevansi keduanya dengan agenda reformasi yakni menegakkan hukum terhadap para pelanggar hak asasi manusia secara sungguh-sungguh, baik dalam dimensi nasional maupun internasional.
\end{abstract}

Kata Kunci: Relevansi; Hukum; Hak Asasi Manusia.

\footnotetext{
*Naskah diterima: 1 Maret 2020, direvisi: 9 Maret 2020, disetujui untuk terbit: 26 Maret 2019

Doi: $10.3376 /$ jch.v5i2.242
} 


\section{PENDAHULUAN}

Hak Asasi Manusia yang selanjutnya disebut HAM merupakan anugerah dari Tuhan yang diberikan kepada manusia untuk dihormati, dijunjung tinggi dan dilindungi oleh Negara, pemerintah dan setiap orang demi kehormatan serta perlindungan terhadap harkat dan martabat manusia itu sendiri.

Hal di atas selaras dengan Pasal 1 (1) UU Nomor 39 Tahun 1999 tentang Hak Asasi Manusia yang mendefinisikan HAM sebagai

"Seperangkat hak yang melekat pada hakikat manusia sebagai makhluk Tuhan yang Maha Esa dan merupakan anugerah-Nya yang wajib dihormati, dijunjung tinggi dan dilindungi oleh Negara, hukum, Pemerintah dan setiap orang demi kehormatan serta perlindungan harkat dan martabat manusia". (Indonesia, 1999)

Definisi tersebut menunjukkan bahwa adanya HAM semata-mata karena manusia adalah makhluk ciptaan Tuhan, yang berbeda dengan makhluk ciptaan lainnya. Hak asasi itu juga ada sematamata karena hadiah tanpa pamrih dari Tuhan agar manusia dapat hidup sungguh-sungguh sebagai manusia. (Sabon \& SH, 2020: 7) Selain itu, Indonesia sebagai negara hukum juga memberi jaminan terhadap perlindungan HAM dalam konstitusinya. Artinya, melindungi, menghormati dan menjunjung tinggi HAM merupakan bagian dari salah satu amanah konstitusi yang wajib dijalankan dalam penyelenggaraan negara di Indonesia. (Tahir, 2015: 405-428)

Secara kodrati, setiap manusia selain hidup sebagai individu, juga selalu hidup bersama dengan manusia lainnya karena manusia adalah makhluk sosial (zoon politicon). Dalam menjalani hidup sebagai individu, manusia berelasi dengan dirinya sendiri, berfikir, hidup bebas dan mampu menilai diri sendiri sehingga melampaui keadaan alamiah. Berkaitan dengan itu, manusia mempunyai hak asasi yang tidak dapat dikurangi dalam keadaan apapun.

Namun, dalam hal menjalani kehidupan sebagai makhluk sosial, ia berinteraksi dengan manusia yang lain. Dalam hal ini, manusia juga mempunyai hak asasi yaitu hak sosial; suatu hak asasi yang tidak boleh melanggar hak asasi orang lain, karena itu dibatasi oleh undang-undang.

Adapun hal menarik dari problematika HAM ini adalah bahwa ketika masyarakat dunia memandang konsep HAM tersebut secara berbeda. Antara masyarakat di Negara A dengan masyarakat di Negara B hampir dapat dipastikan memahami konsepsi tentang HAM itu berbeda, belum lagi di Negara C dan seterusnya. Kalau boleh penulis golongkan Negara di dunia ini menjadi dua kelompok, yakni Negara barat dan Negara timur. Di mana Negara barat identik dengan bangsa Amerika dan Eropa, sedangkan Negara timur identik dengan Negara-Negara di benua Asia. Dengan sendirinya pemahaman 
Ismail Marzuki, Faridy: Relevansi Hukum Dan Hak Asasi Manusia Dengan Agenda...

masyarakat yang ada di kedua Negara tersebut pasti berbeda tentang HAM.

Oleh karena itu, diperlukan suatu acuan bagi seluruh Negara di dunia yang memuat aturan tentang HAM, paling tidak yang mendekati kesamaan di antara berbagai Negara tersebut, khususnya dalam hal penegakan hukum terhadap pelanggar-pelanggar HAM itu sendiri.

Dari uraian singkat di atas, penelitian ini akan berbicara mengenai relevansi hukum dan HAM dengan agenda reformasi, baik dalam dimensi nasional maupun dimensi internasional.

\section{METODE PENELITIAN}

Pada penulisan artikel ini peneliti menggunakan jenis penelitian hukum normatif yaitu penelitian dilakukan dengan cara meneliti bahan pustaka (data sekunder) yang datanya diperoleh dari penelitian, jurnal, buku, maupun berita media massa baik cetak maupun elektronik yang berkaitan dengan penegakan hukum dan hak asasi manusia. Sehubungan dengan penulisan ini, penulis menggunakan metode penelitian normatif, maka dari itu dilakukan pendekatan dengan jalan menelaah norma-norma hukum, doktrin dari para ahli hukum dan peraturan perundang-undangan terkait dengan penegakan hak asasi manusia.

\section{HASIL DAN PEMBAHASAN}

\section{Relevansi Hukum dan HAM dengan Agenda Reformasi Dimensi Nasional}

Secara resmi Deklarasi Hak Asasi Manusia Bangsa Indonesia telah lebih dahulu dirumuskan dari pada Deklarasi
Universal Hak Asasi Manusia PBB, karena pembukaan UUD 45 dan pasalpasalnya diundangkan pada tanggal 18 Agustus 1945, sedangkan Deklarasi Universal Hak asasi manusia PBB adalah tahun 1948. Hal ini merupakan fakta sejarah, bahwasanya sebelum tercapainya hak-hak asasi manusia sedunia oleh PBB, Indonesia telah mengangkat hak-hak asasi manusia dan melindunginya dalam kehidupan bernegara. (Handayani, 2014: 2)

Hal ini juga telah ditekankan oleh para pendiri negara, misalnya pernyataan Moh. Hatta dalam sidang BPUPKI sebagai berikut: "Walaupun yang dibentuk itu negara kekeluargaan, tetapi masih perlu ditetapkan beberapa hak dari warga negara agar jangan sampai timbul negara kekuasaan (Machsstaat atau negara penindas)". (Handayani, 2014: 2)

Sebelum amandemen UUD 1945, satu-satunya HAM universal hanya terdapat di dalam pembukaan UUD 1945 alinea pertama, yaitu "... Kemerdekaan itu ialah hak segala bangsa ...". (Sabon \& SH, 2020: 52) Dalam pernyataan tersebut terkandung pengakuan secara yuridis tentang hak asasi manusia yang menyangkut kemerdekaan sebagaimana tercantum dalam Pasal I Deklarasi Universal Hak Asasi Manusia PBB.

Secara filosofis, hak asasi manusia bukanlah semata kebebasan individualis, melainkan menempatkan manusia dalam hubungannya dengan bangsa (makhluk sosial), sehingga hak asasi manusia tidak dapat dipisahkan dengan kewajiban asasi manusia. 
Kemudian ketika MPR RI melakukan amandemen UUD 1945 yang kedua pada tanggal 18 Agustus 2000, ditambahkan satu bab khusus dalam UUD 1945 tersebut, yaitu Bab XA tentang Hak Asasi Manusia yang berisi 10 pasal, mulai dari pasal 28A hingga 28J. Semuanya merupakan HAM universal, karena perumusannya selalu dimulai dengan "setiap orang" tanpa membedakan apakah warga negara Indonesia atau bukan. Keberadaan pasal-pasal tentang HAM dalam Bab XA UUD 1945 tersebut membuktikan bahwa Indonesia adalah negara hukum yang berkomitmen mengakui dan menghormati HAM. (Isra, 2016: 409-427)

Rujukan yang yang melatarbelakangi rumusan $\mathrm{Bab}$ XA tersebut adalah Ketetapan MPR Nomor XVII/MPR/1998. Kemudian pada tanggal 23 September 1999 diberlakukan UU No. 39 tahun 1999 tentang HAM yang berlandaskan pada Ketetapan MPR Nomor XVII/MPR/1998. (Haryanto, Suhardjana, Komari, Fauzan, \& Wardaya, 2013: 139) UU No 39 tahun 1999 ini memuat norma-norma atau prinsip-prinsip HAM yang dihasilkan dari berbagai deklarasi, konvensi maupun statuta roma. UU tersebut terdiri atas 11 Bab dan 106 pasal, yang antara lain memuat hak-hak sebagai berikut:

a. Hak untuk hidup (pasal 9)

b. Hak berkeluarga dan melanjutkan keturunan (pasal 10)

c. Hak memperoleh keadilan (17-19)

d. Hak atas kebebasan pribadi (pasal 20-27)

e. Hak atas rasa aman (pasal 28-35), dan seterusnya.
Di samping sebagian hak asasi yang telah disebutkan di atas, dalam UU No 39 tahun 1999 juga memuat tentang kewajiban asasi manusia, yaitu seperangkat kewajiban yang apabila hak dilaksanakan tidak memungkinkan terlaksana dan tegaknya hak asasi manusia (pasal 1 butir 2).

Keberadaan UU No 39 tahun 1999 merupakan salah satu instrumen HAM nasional, di mana negara mengakui akan hak-hak manusia, yaitu bahwa setiap orang dilahirkan bebas dan memiliki harkat dan martabat yang sama, dikaruniai akal dan hati nurani untuk hidup bermasyarakat, berbangsa dan bernegara. Setiap orang berhak atas perlindungan dan kepastian hukum dan perlakuan yang sama dihadapan hukum dan pemerintahan. Perlakuan yang sama bukan dalam arti sama rasa sama rata, melainkan kesebandingan yang serasi, selaras dan seimbang antara hak dan kewajiban menurut status dan fungsi seseorang di masyarakat serta akses individu terhadap sarana dan prasarana untuk mengembangkan dirinya. (Sabon \& SH, 2020: 53)

Kemudian dalam rangka penegakan HAM di Indonesia, negara harus memperhatikan dan melindungi perbedaan dan kebutuhan masyarakat hukum adat. Demikian pula, terhadap segala bentuk identitas budaya masyarakat hukum adat, termasuk hak atas tanah ulayat (pasal 6), di mana perlindungan hakikatnya merupakan pemberian jaminan atas keamanan, ketentraman, kesejahteraan, dan 
Ismail Marzuki, Faridy: Relevansi Hukum Dan Hak Asasi Manusia Dengan Agenda...

kedamaian, baik di masa sekarang, nanti dan yang akan datang. (Said, 2018: 145)

Agar semua hak dan kebebasan dasar manusia yang diatur dalam UU No 39 tahun 1999 dapat ditegakkan sebagaimana mestinya, dalam arti penindakan terhadap para pelanggar HAM, maka pemerintah mengeluarkan UU No. 26 tahun 2000 tentang pengadilan HAM. Salah satu sumber perumusan UU No. 26 tahun 2000 ini adalah Statuta Roma 1998 tentang Mahkamah Pidana Internasional dan dokumen terkait, seperti Elements of Crime (2000) dan Rules of Prosedure and Evidence (2000). (Muladi, 2014: 1)

Namun, ada perbedaan pendapat yang sangat signifikan antara pelanggaran HAM berat yang ditetapkan dalam UU No. 26 tahun 2000 dengan yang ditetapkan dalam Statuta Roma. Dalam UU No 26 tahun 2000 pelanggaran HAM berat hanya ada dua macam, yaitu kejahatan genosida dan kejahatan terhadap kemanusiaan. (Indonesia, 2000) Beberapa kasus pelanggaran HAM berat yang pernah terjadi di Indonesia antara lain; kasus Tanjung Priok (1984) dan kasus Timtim (1999) yang diselesaikan di Pengadilan HAM Ad Hoc melalui Keppres No. 53 Tahun 2001 jo Keppres No. 96 Tahun 2001, serta kasus Abepura (2000) yang diproses hukum berdasarkan UU No. 26 Tahun 2000. Dalam tiga kasus tersebut, para pelaku pelanggaran HAM berat kategori kejahatan terhadap kemanusian dituntut berdasarkan prinsip pertanggungjawaban dan telah diputus bebas serta berkekuatan hukum tetap, alasannya ialah karena para pelaku bukan merupakan bawahan terdakwa, di mana terdakwa secara hierarkis tidak memiliki garis komando dan pengendalian yang efektif terhadap para pelaku yang notabene bukan anak buahnya. (Setiyono, 2010: ix)

Sedangkan Statuta Roma menetapkan empat macam yang termasuk kategori pelanggaran HAM berat, yaitu:

a. Tindak pidana Genocide (pembunuhan massal),

b. Kejahatan terhadap kemanusiaan,

c. Kejahatan perang, dan

d. Kejahatan agresi. (Rahim, 2017)

Perbedaan tersebut terjadi karena beberapa alasan, di antaranya adalah: (Sabon \& SH, 2020: 56-57)

a. Belum dapat diberlakukannya Statuta Roma hingga saat ini, karena belum diratifikasi oleh 60 negara. Indonesia bukan hanya belum meratifikasi, melainkan belum menyatakan persetujuannya. Walaupun demikian, ada bagian tertentu dalam Statuta Roma yang dianggap penting bagi Indonesia. Seperti jenis pelanggaran HAM berat tersebut.

b. Indonesia cenderung mengikuti pola civil law system, yaitu memegang teguh prinsip pengakuan, proteksi dan promosi HAM yang telah ditetapkan dalam konstitusi Indonesia, yaitu UUD 1945. Berdasarkan pasal 28J (2) UUD 1945 bahwa setiap orang wajib tunduk kepada pembatasan atas hak dan kebebasan orang lain,...dst. dengan pertimbangan tersebut UU No. 26 
Tahun 2000 telah menetapkan pembatasan terhadap dua macam pelanggaran HAM berat yang setiap orang harus tunduk pada dua macam pelanggaran tersebut.

c. Indonesia merupakan negara merdeka yang berdaulat penuh. Atas dasar kedaulatan ini, UU No. 26 Tahun 2000 tidak harus sama persis dengan Statuta Roma, yang hanya berstatus sebagai sebuah penjanjian internasional.

Berkaitan dengan pola penyelesaian pelanggaran HAM berat masa lalu berdasarkan mekanisme pengadilan nasional, semua upaya hukum yang ada di tingkat nasional harus digunakan semaksimal mungkin terlebih dahulu sebelum menempuh mekanisme remedi di tingkat internasional dan regional. Hal ini sesuai dengan prinsip "exhaustion of domestic remedies" yang dianut oleh hukum internasional. (Romano, 2013: 561-572) Jadi, mekanisme remedi internasional diperlukan ketika mekanisme remedi nasional tidak berjalan secara efektif sehingga menimbulkan ketidakadilan bagi korban.

Menurut Muladi, terdapat empat (4) hal penting yang dapat dijadikan sebagai pedoman dalam menentukan telah terjadinya pelanggaran HAM berat kategori kejahatan terhadap kemanusiaan, sehingga pelakunya dapat dituntut dan diadili, yaitu: (Tahir, 2015: 405-428)

a. Adanya "abuse of power" dalam kerangka asosiasi dengan pemerintah, termasuk di dalamnya delik omisi (violation by omission).

b. Kejahatan tersebut dianggap merendahkan harkat maupun martabat manusia dan pelanggaran atas asas-asas kemanusiaan yang paling mendasar.

c. Perbuatan tersebut dikutuk secara internasional sebagai hostis humanis generis.

d. Kejahatan tersebut dilakukan secara sistematik dan meluas.

Di samping itu, berdasarkan prinsip yurisdiksi universal, setiap negara memiliki kompetensi untuk melaksanakan yurisdiksinya dalam hal mengadili para pelaku pelanggaran HAM berat internasional yang terjadi di tingkat nasional, seperti kejahatan genosida, kejahatan perang dan lainnya. Penggunaaan yurisdiksi universal tersebut adalah untuk mencegah adanya tempat berlindung bagi pelaku kejahatan HAM. Dengan sistem ini, terhadap pelaku yang berada di wilayah yurisdiksi suatu negara, negara tersebut harus mengadili dan menghukum pelaku berdasarkan hukum pidananya atau mengektrasdisi ke negara lain yang memiliki dan hendak melaksanakan yurisdiksinya. (Komar, Etty, \& Damian, 1999: 680)

Hal itu selaras dengan ketentuan Pasal 2 ayat 1 Piagam PBB yang secara tegas menyatakan "The Organization is based on the principle of the sovereign equality of all its Members". Dampak dari pengakuan persamaan kedaulatan tersebut adalah setiap negara berhak menjalankan yurisdiksinya masing-masing dan negara 
Ismail Marzuki, Faridy: Relevansi Hukum Dan Hak Asasi Manusia Dengan Agenda...

lain wajib menghormati dan tidak campur tangan terhadap hal tersebut. (Situngkir, 2018: 660)

Tujuan dari sistem di atas adalah untuk menegakkan supremasi hukum suatu negara, di samping juga karena pertimbangan efektifitas baik dari segi biaya dan waktu untuk memproses penegakan hukum pelaku pelanggar HAM berat tersebut. Oleh karena itu, menurut penulis, menjadi sangat penting bagi Indonesia untuk segera memberikan persetujuan dan meratifikasi Statuta Roma tersebut. Mengingat bahwa negara Indonesia walaupun telah memiliki pengadilan HAM sendiri, namun gagal dalam menjalankan kewajibannya. Karena terkesan ada ketidakinginan untuk mengadili (unwilling) dan ketidakmauan (unable).

\section{Relevansi Hukum dan HAM dengan Agenda Reformasi Dimensi Internasional}

Seiring dengan perkembangan sistem hukum internasional yang berkembang pada abad ke-19, berbagai usaha mulai dilakukan untuk menciptakan suatu yurisdiksi yang dapat menjangkau seluruh Negara tanpa terhalang oleh prinsip kedaulatan dalam menegakkan kewajiban-kewajiban internasional, misalnya mengenai HAM. Pada tahun 1994, di dalam sidang Majelis Umum PBB (United Nations General Assembly) dicetuskan wacana untuk mendirikan suatu peradilan pidana internasional yang independen, dengan menggunakan susunan Statuta Komisi Hukum Internasional (International Law
Commissions). (Aristo M.A. Pangaribuan, 2013: 29)

Statuta tersebut lahir pada tahun 1948, di mana pada waktu itu Statuta tersebut telah memasukkan kejahatan perang, agresi, genosida dan kejahatan kemanusiaan sebagai suatu kejahatan yang dapat diadili di depan peradilan internasional yang independen dan di bawah suatu konsep yurisdiksi yang universal. Sehingga akhirnya pada tanggal 15 Juni 1998 konferensi diplomatic untuk pendirian Mahkamah Pidana Internasional diadakan di Roma yang diikuti oleh 160 Negara, termasuk Indonesia.

Setelah melewati pengkajian dan pembahasan yang panjang atas satu persatu provisi dari Statuta Roma, 120 negara peserta konvensi setuju dengan draf akhir Statuta Roma, 21 suara abstain dan 7 suara tidak setuju. Hal ini terjadi dikarenakan sulitnya mencari bentuk kompromi di antara dua sistem hukum yang ada di dunia ini, yaitu civil law dan common law. Di samping itu secara umum, keberatan negara-negara tersebut adalah karena keberadaan Mahkamah Pidana Internasional/ International Criminal Court (ICC) berpotensi melanggar kedaulatan hukum mereka dan meragukan independensi dari ICC. (Aristo M.A. Pangaribuan, 2013: 30-32)

ICC merupakan lembaga hukum independen dan permanen, yang dibentuk oleh masyarakat negara-negara internasional untuk menjatuhkan hukuman kepada pelaku kejahatan menurut hukum internasional yang tercakup dalam Statuta Roma ini, yaitu 
genosida, kejahatan terhadap kemanusiaan, kejahatan perang dan kejahatan agresi militer.

Jadi dapat dipahami bahwa keberadaan mahkamah pidana internasional yang memiliki yurisdiksi materi terhadap kejahatan-kejahatan berat tersebut merupakan refleksi atas kerja sama internasional untuk memonitor dan mengadili kejahatan tersebut yang menimbulkan keprihatinan internasional. (Muladi, 2014b)

Tujuan ICC adalah (1) bertindak sebagai pencegah terhadap orang yang berencana melakukan kejahatan serius menurut hukum internasional. mengusahakan supaya para korban dan keluarganya bisa memiliki kesempatan untuk mendapatkan keadilan dan kebenaran serta memulai proses rekonsiliasi. (Suparman Marzuki, 2012: 65)

Namun, seperti yang diuraikan sebelumnya bahwa masih ada beberapa Negara yang menentang dan khawatir dengan adanya ICC ini dengan berbagai alasan seperti yang telah disebutkan. Kekhawatiran tersebut lebih karena kurang memahaminya secara mendalam tentang prinsip-prinsip yang dianut oleh Statuta Roma itu sendiri. Salah satunya adalah prinsip komplementer yang termuat jelas dalam pasal 10 pembukaan yang menegaskan bahwa ICC adalah pelengkap (komplementer) peradilan nasional. Artinya, ICC baru digunakan jika pengadilan nasional tidak mau/enggan dan tidak mampu untuk mengadili para pelaku tersebut.

\section{SIMPULAN}

Dari pemaparan dalam pembahasan di atas, terlihat jelas bahwa antara hukum dan HAM memiliki hubungan yang sangat erat. Keduanya saling membutuhkan satu sama lain, dalam rangka penegakan supremasi hukum itu sendiri.

Dalam rangka mewujudkan ketertiban dunia sebagaimana yang telah dituangkan dalam UUD 1945, maka Indonesia sebagai Negara hukum, harus segera mempertimbangkan apa yang telah dikaji dan dibahas di dalam Statuta Roma, yang kemudian melahirkan Mahkamah Pidana Internasional (ICC). Kehadiran mahkamah pidana internasional merupakan suatu langkah maju dalam agenda reformasi hukum, baik dalam dimensi nasional maupun internasional.

Hal ini karena terhadap kejahatankejahatan HAM berat, seperti genosida, kejahatan terhadap kemanusiaan, kejahatan perang dan agresi, merupakan kejahatan serius yang menjadi musuh seluruh bangsa. Dalam ranah nasional, sedikit sekali pelaku kejahatan ini diadili oleh pengadilan nasional. Hal ini tidak lepas karena kejahatan tersebut sering kali melibatkan para petinggi Negara atau bahkan famili dari para elit bangsa yang memegang kekuasaan atas Negara tersebut, seperti Peristiwa 1965 dan kasus penembakan misterius 1982-1985.

Oleh karena itu, ketika Negara terkait tidak mampu (unable) dan tidak mau/enggan (unwilling) untuk mengadili para pelaku kejahatan HAM berat, 
Ismail Marzuki, Faridy: Relevansi Hukum Dan Hak Asasi Manusia Dengan Agenda...

menjadi penting kemudian peran dan fungsi dari adanya ICC ini. Tujuannya adalah agar korban dan keluarganya mendapatkan keadilan dan kebenaran substantif.

\section{UCAPAN TERIMA KASIH}

Puji dan Syukur penulis ucapkan ke hadirat Allah SWT yang telah memberikan Rahmat dan Karunia-Nya, sehingga akhirnya penulis dapat menyelesaikan penulisan karya ilmiah ini yang berjudul: "Relevansi Hukum Dan Ham Dengan Agenda Reformasi: Dimensi Nasional Dan Internasional"

Bantuan dan dorongan dari berbagai pihak tidak mungkin karya ilmiah ini dapat diselesaikan. Oleh karena itu pada kesempatan ini dengan segala kerendahan hati, penulis ingin mengucapkan terima kasih dan penghargaan yang sebesarbesarnya kepada:

1. Bapak KH. Abdul Hamid Wahid, M.Ag, selaku Rektor Universitas Nurul Jadid (UNUJA), PaitonProbolinggo.

2. Seluruh rekan-rekan Dosen Universitas Nurul Jadid (UNUJA) yang tidak dapat penulis sebutkan satu-persatu.

\section{DAFTAR PUSTAKA}

\section{Buku-Buku}

Aristo M.A. Pangaribuan. (2013). Perdebatan Menuju Mahkamah Pidana Internasional. Jakarta: Papas Sinar Sinanti dan Badan Penerbit FHUI.

Komar, M., Etty, R. A., \& Damian, E. (1999). Mochtar Kusumaatmadja:
Pendidik dan Negarawan Kumpulan

Karya Tulis Menghormati 70 Tahun

Prof. Dr. Mochtar Kusumaatmadja,

SH, LL. M. Bandung: Bandung, Alumni.

Sabon, M. B., \& SH, M. (2020). Hak Asasi Manusia: Bahan Pendidikan untuk Perguruan Tinggi. Penerbit Universitas Katolik Indonesia Atma Jaya.

Suparman Marzuki. (2012). Pengadilan HAM di Indonesia; Melanggengkan Impunity. Jakarta: Erlangga.

\section{Jurnal}

Handayani, Y. (2014). Pengaturan Hak Asasi Manusia Dalam Konstitusi Indonesia Dan Konstitusi Amerika Serikat. Jurnal Rechtsvinding Online. Tanpa Volume, Tanpa Nomor.

Haryanto, T., Suhardjana, J., Komari, A. K. A., Fauzan, M., \& Wardaya, M. K. (2013). Pengaturan tentang Hak Asasi Manusia Berdasarkan Undang-Undang Dasar 1945 Sebelum dan Setelah Amandemen. Jurnal Dinamika Hukum, 8(2), 136144.

Isra, S. (2016). Peran Mahkamah Konstitusi dalam penguatan hak asasi manusia di Indonesia. Jurnal Konstitusi, 11(3), 409-427.

Rahim, A. (2017). Urgensi Ratifikasi Statu Roma Wujud Eksistensi Mahkamah Pidana Internasional (International Criminal Court) dalam Penyelesaian Kasus Pelanggaran HAM. Jurnal Al Himayah, 1(1), 1-24. 
Said, M. F. (2018). Perlindungan Hukum Terhadap Anak Dalam Perspektif Hak Asasi Manusia. JCH (Jurnal Cendekia Hukum), 4(1), 141-152.

Situngkir, D. A. (2018). Eksistensi Kedaulatan Negara dalam Penerapan Yurisdiksi Mahkamah Pidana Internasional. Lex Librum: Jurnal Ilmu Hukum, 4(2), 659-672.

Tahir, A. (2015). Reformasi dan Perlindungan Hak-hak Tahanan dan Narapidana di Lembaga Pemasyarakatan. Supremasi Hukum, 4(2), 405-428.

\section{Peraturan Perundang-undangan}

Indonesia, R. (1999). Undang-Undang Republik Indonesia nomor 39 tahun 1999 tentang hak asasi manusia. Pusat Penerbitan PNRI.

Indonesia, R. (2000). Undang-undang No. 26 Tahun 2000 Tentang Pengadilan HAM. Lembaran Negara Tahun.

\section{Makalah dan Tugas Akhir}

Muladi. (2014a). Hukum Acara Pengadilan HAM (p. 1). p. 1.
Semarang: Bahan Ceramah di MIH UNDIP dan USM.

Muladi. (2014b). Relevansi UU No. 26 Tahun 2000 dengan Pengadilan HAM Ad Hoc internasional dan Statuta Roma 1998 (p. 198). p. 198. Semarang: Sari Kuliah Hukum dan HAM.

Romano, C. P. R. (2013). The rule of prior exhaustion of domestic remedies: theory and practice in international human rights procedures. In International Courts and the Development of International Law (pp. 561-572). Springer.

Setiyono, J. (2010). Pertanggungjawaban Komando (Command Responsibility) Dalam Pelanggaran Ham Berat (Studi Kasus Kejahatan Terhadap Kemanusiaan Di Indonesia). Universitas Diponegoro. 